\title{
The transformative role of universities in regional innovation systems
}

\author{
Lessons from university engagement in cross-border regions
}

\section{CHEPS WORKING PAPER 05/2017}

Jos van den Broek. Rathenau Instituut and Radboud University Nijmegen

j.vandenbroek@rathenau.nl

Franziska Eckardt. CHEPS (University of Twente)

f.eckardt@utwente.nl

Paul Benneworth. CHEPS (University of Twente)

p.benneworth@utwente.nl

\section{Series Editor Contact:}

Nadine Zeeman, Katharina Lemmens-Krug \& Paul Benneworth

Centre for Higher Education Policy Studies

University of Twente

P.O. Box 217

7500 AE Enschede

The Netherlands

T $\quad+3153-4893263$

F $\quad+3153-4340392$

E n.zeeman@utwente.nl

W www.utwente.nl/cheps 


\section{Table of Contents}

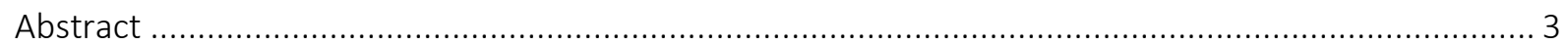

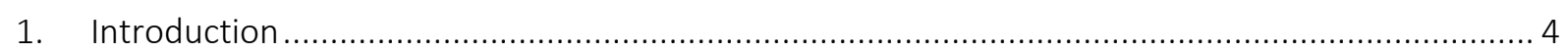

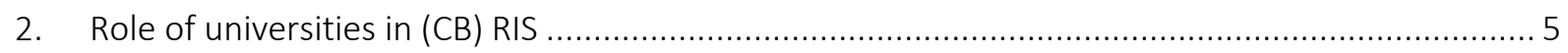

2.1 Regional innovation systems in the cross border contexts ................................................ 6

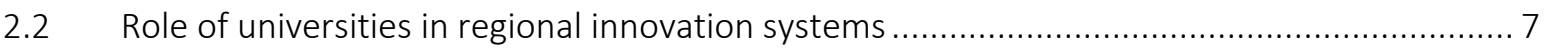

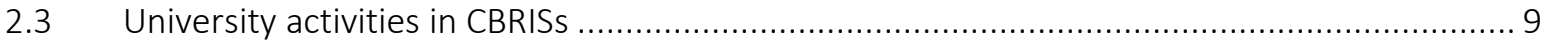

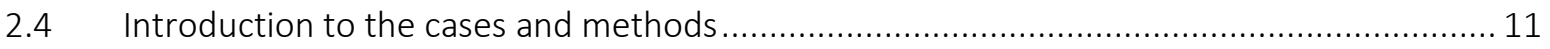

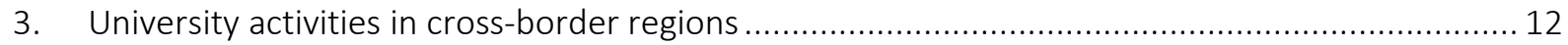

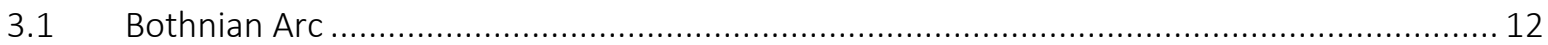

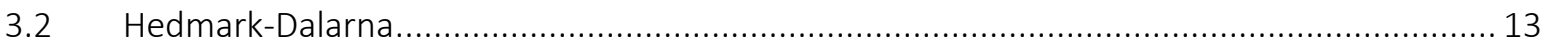

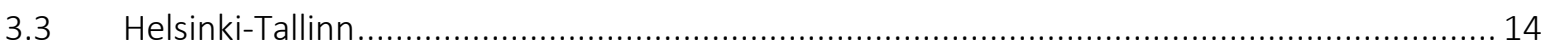

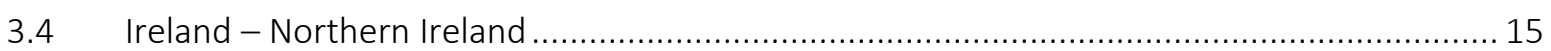

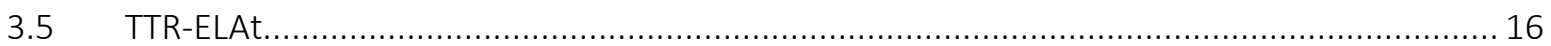

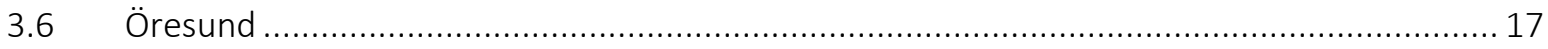

4. A first characterisation of the transformative effects of universities in CBRISs ........................... 19

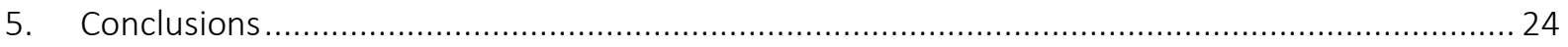

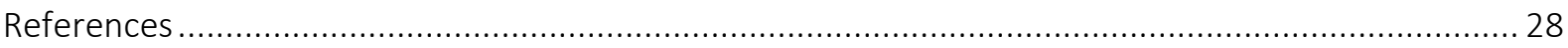




\section{Abstract}

Universities play many important roles in the knowledge-based economy, providing innovation support services directly, but also changing the way that innovation is organised in their regions, and building new economic development pathways. Their roles can be particularly important in less successful regions that lack a critical mass of other knowledge actors who have the skills to organise regional innovation structures and processes. This working paper seeks to explore the roles that universities can play in one very specific type of peripheral region namely cross-border regions, where national borders hinder interactions, network-formation and institutionalisation between innovation actors that might geographically be proximate. Our research question is: what roles do universities play in cross-border regions and how can we understand these roles through a conceptual typology? We propose a conceptual typology for how universities may build up elements of university innovation activities in cross-border regions using their teaching, research, management and administrative processes. We explore this in six border regions: Bothnian Arc, Hedmark - Dalarna, Helsinki - Tallinn, Ireland Northern Ireland, TTR-ELAt and Öresund to reflect more widely on universities' wider roles in building up regional innovation systems.

Key words: border regions, cross-border regional innovation, university internationalisation university regional engagement, university third mission 


\section{Introduction}

Universities play an important role in the knowledge-based economy (Mansfield, 1991). Seen from a regional innovation systems (RIS) perspective they are key actors in a region, providing knowledge, resources and human capital (Arbo \& Benneworth, 2007). Universities can be system builders and 'enablers of regional development' (Charles, Kitagawa, \& Uyarra, 2014; 329) creating new systemic connections in the RIS (Gunasekara, 2006b). However, much of the knowledge about universities contributions has been developed in the context of highly successful and innovative regions (see for example Saxenian, 1985, 1992; Seagal 1985; SQW, 2003; Lawton Smith et al, 2003; Lawton Smith, Glasson \& Chadwick, 2005; Tian Miao et al, 2015). In these regions, universities play what Gunasekara (2006a, b, c, d) called a generative role, they provide a set of inputs to regional economic processes that other actors, specifically knowledge exploiters, transform into productive economic activity and wealth.

But in fully understanding the role of universities and regional economic development it is necessary to acknowledge two other kinds of roles that universities can play, what Gunasekara calls the developmental roles and also what might be considered as the transformative role (Ruan et al, 2015). If their generative roles are how they supply inputs to a process, in a developmental role then universities change the architecture of that process, and in transformative actions, they create entirely new development processes. Gunasekara's (2006b) prescription to study these development roles is to look at what he terms non-core regions, the periphery, where these processes typically function in a fairly dysfunctional way being associated with these regions; moderate or low innovation performance (Kempton, 2015). Peripheral regions typically suffer in terms of knowledge based development in either having sparse innovation environments such as on islands, in having locked-in innovation environments in old industrial regions, and having fragmented innovation environments, in non-core cities (Tödtling \& Trippl, 2005). These weak, dysfunctional processes therefore make it easier to distinguish the role of the university in improving the overall quality of those processes as an antecedent step to improving that weak or moderate innovation performance.

In this working paper, we seek to use a similar mode of argumentation to explore the ways that universities can contribute to transformative development, that is to create entirely 
new innovation activities in places, by looking at 'empty' innovation environments where no innovation takes place. And to do this, we look at a particular kind of regional context where there is almost no regional innovation processes, namely cross-border regions, and explore the wider transformative roles of universities in these regions. Border regions are a specific type of peripheral regions, since they suffer from border barriers. Most border regions are peripheral in terms of distance to the centre and policy attention by national governments. But also in more centrally located border regions the development of an integrated cross-border region is mostly a peripheral activity, deemed less important than regional and national issues. Connecting across the border can be a way to mediate this peripherality, but innovation and knowledge spill overs are still hampered by nation-state borders despite the abolishment of internal borders within the EU (Makkonen, 2015).

We conceptualise this specifically as the ways that universities can contribute to building up cross-border regional innovation systems by stimulating innovation connections and other related linkages across the border. On this basis, we develop a conceptual typology for university involvement in cross-border regions. In this working paper, we explore the role that universities can play in cross-border regions, and specifically the active ways in which they develop CBRIS, in terms of developing linkages across the border. Our research question is: what roles do universities play in $\mathrm{CB}$ regions and how can we understand these roles through a conceptual typology? We explore this typology with reference to an OECD study of cross-border innovation in by drawing upon six case study reports that were prepared for an OECD study on cross-border innovation in six border regions: Bothnian Arc, Hedmark - Dalarna, Helsinki - Tallinn, Ireland - Northern Ireland, TTR-ELAt and Öresund (Nauwelaers, Maguire, \& Marsan, 2013a, 2013b, 2013c, 2013d, 2013e, 2013f). On this basis we develop a conceptual typology for university involvement in $\mathrm{CB}$ regions and reflect more widely on the wider development and transformative roles that universities play in building up regional innovation systems as strong building blocks for economic development.

\section{Role of universities in (CB) RIS}




\subsection{Regional innovation systems in the cross border contexts}

The contemporary knowledge economy is one in which the economic prosperity of places rests for a large part upon their capacity to spur innovation (McCann \& Ortega-Argilés, 2013), and the munificence of their regional innovation environments. To address our overall research question, we conceptualize what we have hitherto referred to with the vernacular 'regional innovation environments' as regional innovation systems (RIS) consisting of a knowledge creating and knowledge exploiting subsystem (Cooke, 2005). From this perspective, the problem that cross-border regions face is that there are no networks or organised innovation activities that facilitate the sharing of innovation resources across the border; in effect they have a half-market problem, in which the other side of the border is neglected as both a market and a reservoir of potential collaboration partners (Van Houtum, 1998). Trippl (2010) distinguishes between five building blocks important for a successful cross-border integration leading to integrated cross-border regional innovation systems: the knowledge infrastructure, the business dimension, a relational dimension, a socio-institutional dimension and a governance dimension. According to her a strong cross-border RIS needs 'to mobilise synergies and to amplify the combination of capabilities in knowledge generation and diffusion, various forms of partnerships between research organisations, educational bodies and transfer agencies from adjoining areas are necessary' (Trippl, 2010;152).

Universities aiming to contribute to the strengthening of a CBRIS thus need to build connections across the border, a process that intuitively may be regarded as starting with some first contact, developing into more regular contacts and first attempts of CBC and eventually via diverse stages may lead to more advanced cooperation and relations (Nelles \& Durand, 2014; Van Houtum, 1998). Lundquist \& Trippl (2013) have developed a three-staged model for CBRISs, distinguishing between weakly integrated, semiintegrated and fully integrated systems. Firstly, systems might be entirely disconnected in innovation terms, prior to the development of any contacts (in the absence of the kinds of connections and institutions that foster regular interaction). In weakly integrated systems, there is a lack of connections between the adjacent regions in general, and innovation relations are ad hoc and incidental. Semi-integrated systems display a certain amount of integration and the importance of cross-border connections increases. In fully integrated systems, the contacts and connections are regularly and part of daily routines. 
We should be aware not to think of this model as a teleological model moving only in one direction of more integration. Cross-border collaboration is a process of small steps and drawbacks with the possibility of decline of collaboration and feedback loops exits between the stages (Van den Broek \& Smulders, 2014).

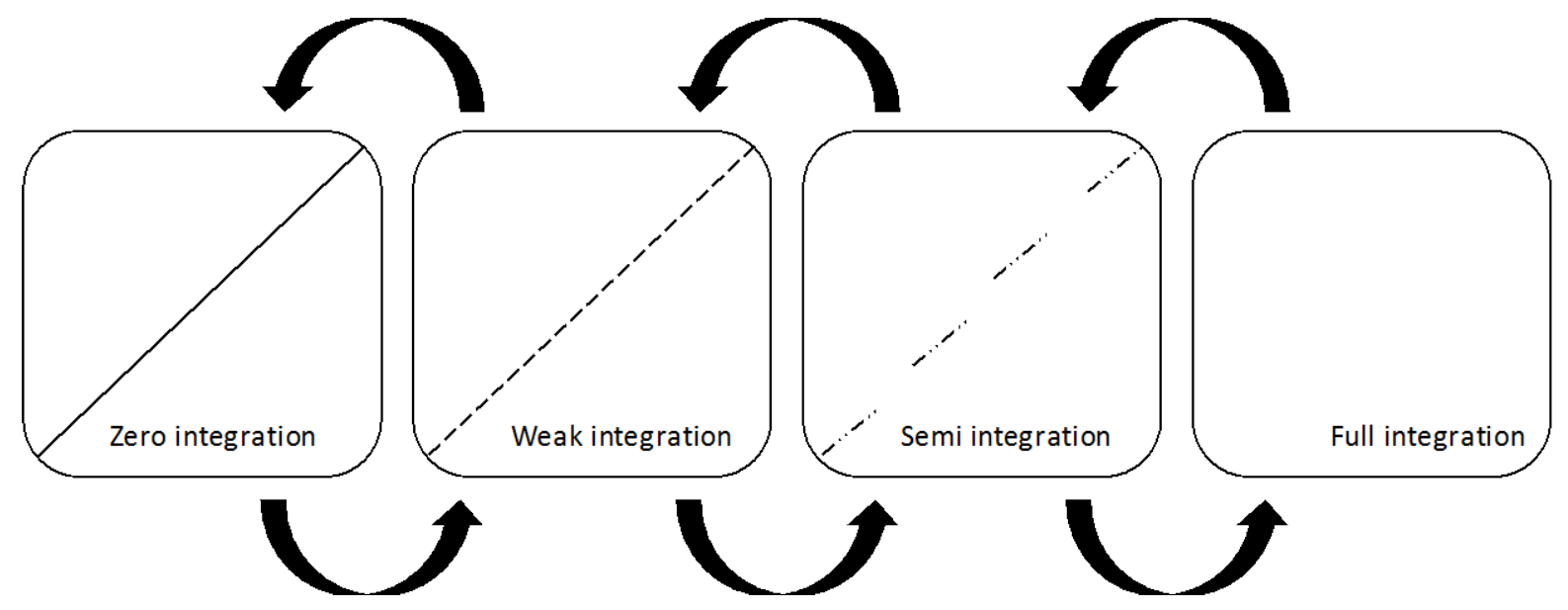

Figure 1. Stage of CBRIS integration (Author's own based on Lundquist \& Trippl, 2013; Van den Broek \& Smulders, 2014)

\subsection{Role of universities in regional innovation systems}

We know that universities can play an important role in regional development in many ways (Arbo \& Benneworth, 2007; Kempton, 2015; Trippl et.al., 2015; Uyarra, 2009). Goddard and Chatterton (2003) conceptualised this role as a region - university dynamic interface where external demands are linked to the internal organisation of the university. At the heart of this are the university core activities, the teaching and research activities, that generate the knowledge that can be used in regional innovation processes (CERI, 1982). At the heart of the idea of the university is that there are internal connections - that the knowledge created in research enriches teaching processes, and that teaching provides connections into society that can enrich research processes (Arbo \& Benneworth, 2007). Even at the time of the 1982 CERI report The University and the Community, that was arguably the first piece of research to really argue that universities did just more than research and teaching, it was clear that external connections were also important to universities (Benneworth, 2014). Universities have always had a degree of 'sponsor dependence' in that their activities are justified by the value they bring to their host societies. What changed in the last fifteen years was a belief by policy-makers that 
this should be more actively managed, and in the context of the introduction of strategic modernisation of universities, that external engagement should be a strategically managed activity for universities.

Although it is easy to agree that universities should create benefits for society, there is what we have elsewhere identified as a scalar slipperiness in this implicit societal duty (Benneworth \& Osborne, 2014). In particular, because the university is connected in so many various ways to society, it becomes hard for any societal partner to assert that the university has a duty to it. Students may come to universities from wider regional or national labour markets, universities need to manage campus estates and student housing locally, whilst they may co-operate with firms and other universities globally in their research and consultancy activities. Universities become sites of complex trade-offs in societal activities, perhaps illustrated most starkly in Hewson's 2007 story of a university that were willing to radically change the character of a village hosting one of their sites in order to attract lucrative external research investment (Benneworth et al, 2013). So it is always necessary to be careful in talking about a societal duty or the third mission in recognising that from a university perspective, those engagement activities only make sense in terms of the ways that they support - bring new resources - back into the university that support those core institutional missions.

Yet, we also know that geography matters; editor of the Economist newspaper Frances Cairncross might have declared in 1997 that geography no longer mattered, but in 2016 a briefing paper from the Economist Intelligence Unit declared in that location mattered, and OECD patenting and citation data demonstrate that nearby collaboration is still relevant for researchers (OECD, 2013). And this is at the heart of the heuristic by which university contributions to their regions can be understood, as a version of Bathelt et al's (2004) “Global pipelines, local buzz" argument, in which universities attract resources to a region and these resources have a positive effect in those regions (Arbo \& Benneworth, 2007). This then gives a second criterion for a successful university contribution to the region, namely that it attracts an external asset to the region, which benefits a regional partner and also directly or indirectly strengthens the university core activities.

The external activities by which university resources may become embedded within wider regional activities encompass all actions that universities undertake in service to 
the region and society. This ranges from commercialization and valorisation to volunteering, opening up facilities, technology transfer and media commentary (Goddard \& Chatterton, 2003; Sánchez-Barrioluengo, 2014). External activities by universities have grown in importance, but there is a great amount of variation in the meaning and importance of this depending on the type of HEI, their location and the way external activities are designed (Sánchez-Barrioluengo, 2014). External activities can be focused upon generating knowledge outputs by commercialization and valorisation of knowledge in the form of patents and spin offs (Gunasekara, 2006a). But can also take the form of contributing to the socio-economic development of the region by, for example, focusing teaching and research on the region, active retention strategies for alumni, participation in associative governance or providing analysis and opinion to key regional actors (Cooke \& Piccaluga, 2004). We stylise these internal-external spanning activities from universities as comprising five different elements, namely [1] education domain activities, [2] research domain activities, [3] third mission activities (commercialization/valorisation), [4] governance activities, and [5] institutional collaboration activities. We now turn to use this five-fold typology as the basis of identifying the range of ways in which universities can have these transformational contributions in cross-border RISs.

\subsection{University activities in CBRISs}

To understand how cross-border activities build up, we should consider the internal and external activities that HEIs undertake in building up connections and relate them to the ways in which CBRISs can be understood to develop. Specifically, we argue that the role played by HEIs in the development of CBRIS differs per stage of the development of CBRIS (Lundquist \& Trippl, 2013), related to the transitions associated with moving between these different stages. We refer to these here as an integration step is defined as activities that lead to more regular contacts and activities in the cross-border region, and facilitate others to become more readily involved with less effort. For example, the setup of a double degree program leads to more regular contacts and activities between HEIs, whilst at the same time it encourages and enables students to become involved in cross-border activities. 
In the education domain the pressure on universities to internationalize, to support lifelong learning and the attempted retention of graduates can be drivers of the transitions (Goddard \& Chatterton, 2003; Power \& Malmberg, 2008). Barriers in this domain can be related to national accreditation rules, nationally driven curricula, language barriers and the lack of cross-border links on the operational level (Ibid.). In the research domain the focus on international exposure and prestige might lead to a low attention for the (border) region (Goddard \& Chatterton, 2003). On the other hand, there are possible new sources of funding and the possibility of sharing facilities with actors on the other side of the border. Nationally driven research agenda's, and the accompanying funding, might hamper integration in this domain (Power \& Malmberg, 2008).

As national incentive structures already form a barrier to regional engagement (Caniëls \& van den Bosch, 2011), cross-border engagement will probably be extra difficult. Establishing links with firms is already challenging for most HEIs (Uyarra, 2010), this will probably be much harder cross-border, where network linkages are lacking (Van den Broek, Benneworth, \& Rutten, 2015a). In terms of governance effects, universities could potentially be involved in participating in collective cross-border institution-formation processes where innovation issues are discussed such as INTERREG programme committees in Europe or innovation platforms (Haselsberger \& Benneworth, 2011; Van den Broek \& Smulders, 2014). Finally we see that universities might also collaborate by creating cross-border higher education spaces via closer institutional interaction with other universities other the border; there have been collaborative attempts in the crossborder Limburg (BE/NL) and Schleswig-Slesvig (D/DE).

To analyse whether and how universities contribute to CBRIS integration we need to think about the different kinds of integration step might be associated with the five activity domains, and table 1 sets out more systematically the ways in which universities domain activities might contribute to integration steps towards each stage of CBRIS integration. This table provides the basis for categorising and exploring the ways that universities contribute to the transformative creation of CBRISs.

Table 1. Characterization of activities in each stage per activity.

$\begin{array}{lll}\text { Stage } 1 & \text { Stage } 2 & \text { Stage } 3\end{array}$




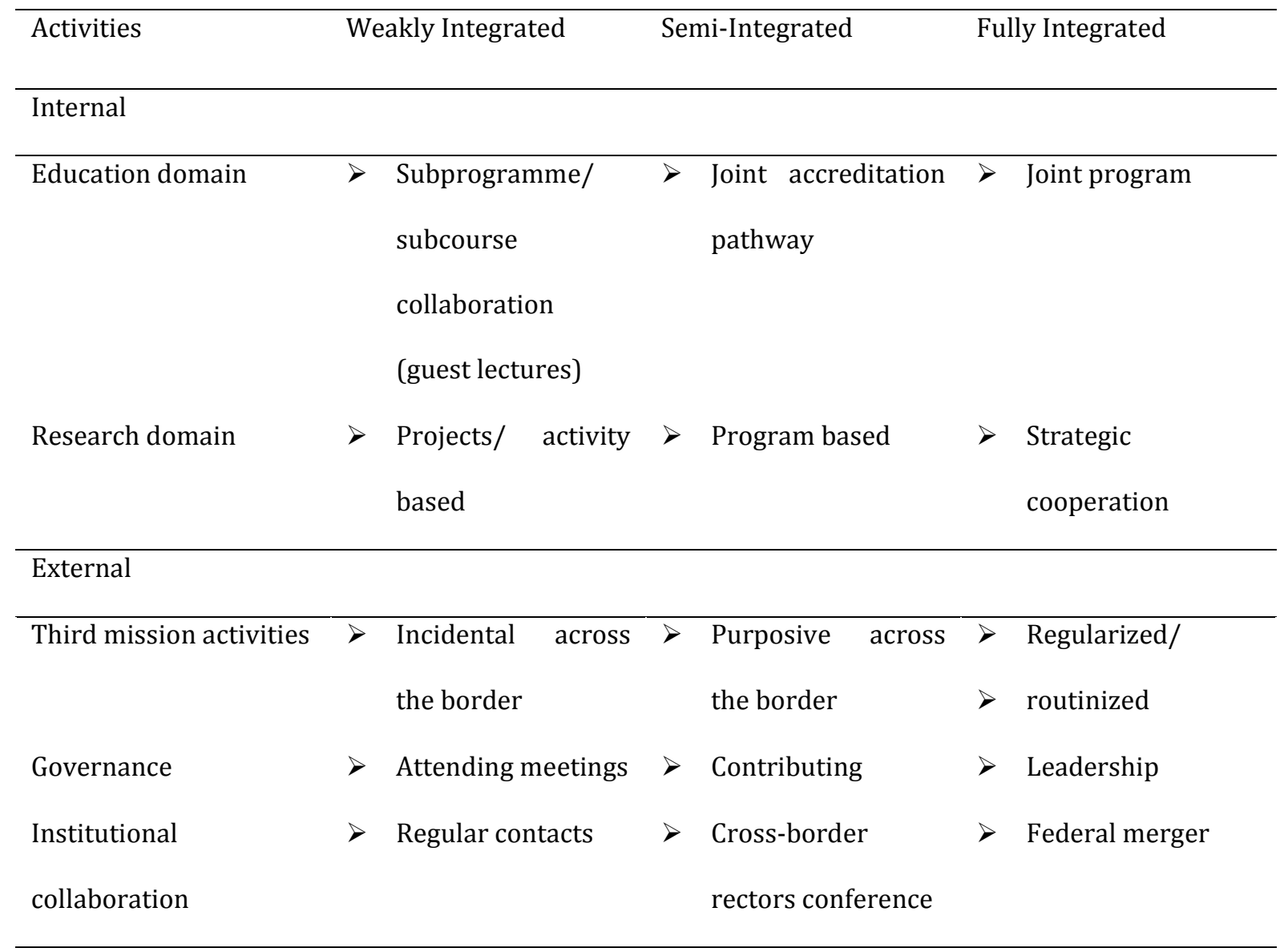

\subsection{Introduction to the cases and methods}

To explore the empirical validity of our typology of university activities in cross-border regions we use OECD study Regions and Innovation: collaborating cross-border in which the OECD systemically analyzed innovation in border regions, the governance of crossborder cooperation and policy instruments for stimulating cross-border innovation (OECD, 2013). This project was undertaken in 2011-13 following the OECD standard review methodology of development of a common reporting format, then the drafting and peer evaluation (by policy experts rather than academic peers) of the document against that format, and then the publication of a final post-peer review document representing the settled consensus. This was carried out by a team within the OECD, and it is those post peer-review reports that we have used as the basis for our analysis of universities' cross-border roles.

We used the OECD case study material because it provides a good overview of what is happening and are replete with empirical details offering a good starting point to test our 
typology. Nevertheless, we acknowledge that the repurposing of secondary research material for an alternative purpose is always problematic, particularly in the sui generis case of higher education research, and this necessitates that we are relatively modest regarding the definitive nature of our findings. We have been particularly curious in making the assumption that the absence of information means that it does not exist, although it does become clear that university activity within CBRIs is relatively limited. For the OECD study six in-depth case studies of border regions were undertaken covering the border regions: Bothnian Arc, Hedmark - Dalarna, Helsinki - Tallinn, Ireland Northern Ireland, Top Technology Region/Eindhoven-Leuven-Aachen Triangle (TTRELAt), and Öresund (Nauwelaers et al., 2013a, 2013b, 2013c, 2013d, 2013e, 2013f). More detail on each region is provided in the next section, which provides an overview of the ways in which HEIs in these six regions are contributing to the development of crossborder regional interaction.

\section{University activities in cross-border regions}

\subsection{Bothnian Arc}

The Bothnian Arc is located in the Northern parts of Sweden and Finland around the cities of Oulu and Luleå. It is a peripheral region with weak internal connections but with rather strong innovation performance on the respective sides (Nauwelaers et.al., 2013e). The region has around 700,000 population spread out across many settlements and these smaller towns, with relatively limited connections between these settlements with the exception of the coastal highway. There is a degree of industrial similarity across the border, with both regions specialising in the traditional wood-based industries (paper, pulp, forestry) as well as ICT sectors. Despite their relative remoteness and sparseness, these are very innovative regions, ranked by the EU regional innovation scoreboards as innovation leaders, not least because of the presence of Nokia in Oulu but also high levels of public sector investment on both sides of the border in innovation activities.

Funded by Interreg IVA Nord programme in the period 2008-11, the University of Oulu and the University of Luleå jointly established the Nordic Mining School, a joint Master degree programme in fields related to the mining industry (Nauwelaers, et al., 2013e). In 
order to bring master students of both universities more together, students are expected to spend at least six months of their studies at the other university. Furthermore, to encourage more entrepreneurship in the fields related to the mining and exploration industry, the Nordic Mining School is offering a joint professorship in "mineral entrepreneurship" since 2010. Regarding research activities, six joint public research programmes as well as two cross-border private research and development funding programmes exist in the Bothnian Arc (Nauwelaers, et al., 2013e). Besides these efforts towards more internal integration between universities in the Bothnian Arc, it is stated in the OECD report that the flows of students and researchers, which take place in the crossborder region is rather limited. One reason for this is that students as well as researchers tend to choose universities further away once they have chosen to leave (Nauwelaers, et al., 2013e). With regard to third mission activities in the Bothnian Arc, five joint crossborder academic-research-business support initiatives have been launched in the area. Furthermore, although both universities are important players in the region, they are not active partners in the governance of the cross-border region, since they are not contributing to the vision and strategy of the border region (Nauwelaers, et al., 2013e). The level of institutional integration between the universities in the Bothnian Arc goes beyond regular contacts. For example, the Nordic Mining School is organised by a steering group that is made up of representatives from the University of Oulu and the University of Luleå.

\subsection{Hedmark-Dalarna}

Hedmark-Dalarna is located on the Swedish-Norwegian border covering two small counties with only 500,000 inhabitants. This peripheral region has weak cross-border connections and a weak innovation performance on both sides (Nauwelaers et.al., 2013a). The region is sparsely populated on either side of the border, with an economy based on traditional extractive industries alongside tourism. This means that the regional productivity is far below both national average rates and highlights the lack of critical mass in knowledge-based activities as the basis for potential specialisation. Each of the two regions has a relatively small university college - this kind of institution is a higher education institution specialised on education and primarily applied research; both teaching and research are intended to be relevant for the local labour market, making 
them similar kinds of universities, although oriented to slightly different research activities.

Internal research and education activities between HEIs in the Hedmark-Dalarna crossborder area are primarily project or activity based (e.g. "distance-learning activities" and "joint research activities") and limited to occasional academic collaboration (e.g. "guest lectures") (Nauwelaers, et al., 2013a, p. 7). Most collaborations and regular contacts between the HEIs in the cross-border region are primary established based on "bottomup co-operation initiatives between individuals in the higher education sector", but not based on polities (Nauwelaers, et al., 2013a, p. 27). Furthermore, no third mission activities seem to take place in the Hedmark-Dalarna cross-border area. Also, universities do not play a key role in the governance of the cross-border region and their cooperation and collaboration takes place at a rather weakly integrated level (Nauwelaers, et al., 2013a).

\subsection{Helsinki-Tallinn}

Helsinki - Tallinn is a metropolitan area covering Southern Finland and Northern Estonia with the Gulf of Finland as natural border. The regions have different industrial specialisation and knowledge bases and an unbalance in innovation performance with Helsinki being a strong innovation hub and Tallinn only performing weak to modest (Nauwelaers et.al., 2013b). The region is strongly affected by Helsinki's status in recent years as the innovation capital of Europe with the highest levels of R\&D investments. Although Tallinn as Estonia's capital is performing strongly in the eastern European context, the fact that it has so far to go to catch up with Helsinki means that there is a strong imbalance in the region reflected in all kinds of cleavages. There is a strong division of labour within the region reflecting the fact that Finnish wages are two to three times higher than comparable wages in Estonia. Likewise, there are huge flows of investment southwards seeking to exploit these factors and this has artificially inflated Estonia's apparent knowledge economy because of the investment in capital stock (machinery) rather than in knowledge generation and exploitation activities.

In the Helsinki-Tallinn cross-border region, cross-border collaboration between the HEIs is highly institutionalised since the early 90s. Internal education and research activities take the forms of "student, teacher and research exchange, joint researcher training, copublishing, joint conferences and EU - funded project cooperation" (Nauwelaers, et al., 14 
2013 b, p. 31 - 32). With regard to education activities, cross-border student flows between HEIs in the Helsinki-Tallinn cross-border region are organised by "Erasmus" and “Nordplus programmes" (Nauwelaers, et al., 2013b, p. 19). In addition, joint doctoral schools and programmes are established in the cross-border area (Nauwelaers, et al., 2013b). Regarding research activities, many bilateral and multilateral research cooperation takes place, especially in the field of public health studies. Furthermore, both countries have expressed their interest in the "European Strategy Forum on Research Infrastructures" to share their research infrastructures in the fields of biosciences, linguistics and social sciences (Nauwelaers, et al., 2013b, p. 32). Although it is reported that major firms and HEIs rather favour cooperation opportunities at an international scale than cross-border cooperation, few attempts have been made, for example the Helsinki-Tallinn Science Bridge. Established in the period 2002-05, the Helsinki-Tallinn Science Bridge project had the aim to develop "cross-border university cooperation for science parks" (Nauwelaers, et al., 2013b, p. 30). Universities from both sides of the border region were key actors the establishment of the project. Moreover, collaboration between the HEIs ranges from ad-hoc and informal bottom-up contacts and collaborations over joint discussions in research council to formal participation in the Baltic University Programme ("network of 25 HEIs in the Baltic Sea Regions") (Nauwelaers, et al., 2013b, p. 19).

\subsection{Ireland - Northern Ireland}

Ireland-Northern Ireland is located on the Isle of Ireland covering Ireland and Northern Ireland, which is part of the United Kingdom. The area consists of two medium-sized metropolitan areas, Dublin and Belfast, with similarities in terms of innovation performance but differences in economic specialization (Nauwelaers et.al, 2013c). There has been a strong divergence of economic performance across the border: the case of the Republic of Ireland is well known, with the so-called "Celtic Tiger" transformation of the 1990s and 2000s eventually being undermined by financial overstretch and the fallback on multi-lateral creditors for a bailout. North of the border has seen a similar story to elsewhere in the United Kingdom, with peripheral old industrial regions hit by the restructuring of publically owned industries producing mass unemployment and the gradually collapse of private business investment; in the 1990s Northern Ireland was by 
some considerable margin the poorest region in the UK but has subsequently caught up with Wales and the north east of England.

To foster more cross-border doctoral research mobility in the Ireland-Nothern Ireland cross-border region, a joint initiative, called "Innovation Academy" was established by HEIs at both sides of the border. The Innovation Academy offers joint courses in innovation and entrepreneurship for doctoral students (Nauwelaers, et al., 2013c, p. 34). Regarding research activities, HEIs in the Ireland-Nothern Ireland cross-border region seem to focus more on a global rather than cross-border scale. Most cross-border research activities that take place between the cross-border universities are based on bottom-up initiatives. Research collaboration, however, increased through HEIs participation in the "EU Seventh Framework Programme" and the "US-Ireland R\&D Partnership" (Nauwelaers, et al., 2013c, p. 25). Moreover, further joint research projects are planned for the future (as mentioned in the "Northern Ireland Draft Innovation Strategy 2013-2025") (Nauwelaers, et al., 2013c, p. 29). Concerning HEIs' third mission activities, not many initiatives are reported. It is reported that universities seem to "support the economy", however, these efforts "should not be overestimated" (Nauwelaers, et al., 2013c, p. 25). The FUSION programme, however, shows an example for a programme that funds students and skilled graduates working in firms in both side of the border (Nauwelaers, et al., 2013c). With regard to the role of HEIs in the governance structure of the Ireland-Nothern Ireland cross-border region, universities play a relatively limited active role. Furthermore, although much bottom-up cooperation between HEIs in the Ireland-Nothern Ireland cross-border region is reported, cooperation does not take place at an institutionalised level yet.

\subsection{TTR-ELAt}

TTR-ELAt is an area consisting of a network several medium-sized cities, most notably Eindhoven, Leuven and Aachen, in the Netherlands, Belgium and Germany. It is a region with strong accessibility, many economic complementaries and a strong innovation performance in all regions (Nauwelaers et.al, 2013f). With regard to education and research activities, there is a high level of cooperation reported for the TTR-ELAt. Although much of the region was traditionally a mining region and that industry went through a dramatic period of transition in the 1960s, the region has retained a strong industrial base, although that also faces the pressures of competition and 16 
deindustrialisation. The three main cities each host world-class universities that are distinguished by close links to their host regions - the universities in both Aachen and Eindhoven are technical universities, whilst the university in Leuven is Belgium's preeminent HEI. The biggest challenge for this region is that each of the sub region has its own specialisation and those specialisations are sufficiently distinct to reduce the potential latitude for closer co-operation and the development of synergy.

In 2001, a Transnational University Limburg was established (joint Flanders and Dutch) with the aim to "jointly undertake research and offer degree programmes in life sciences and computer sciences" (Nauwelaers, et al., 2013f, p. 41). Further joint education programmes can be found in the fields of medical imagery (executive master programme) and entrepreneurship (ELAt Master classes) (Nauwelaers, et al., 2013f). With regard to joint research programmes, many different forms of joint research initiatives and joint research infrastructures have been established in the TTR-ELAt (e.g. Holst Centre (joint Flanders-Dutch initiative), biomedical research centre (AMIBM, joint Dutch-German initiative)). Besides that, there is a number of project-based R\&D projects involving both public and private research actors in the TTR-ELAt (Nauwelaers, et al., 2013f). With regard to third mission activities in the TTR-ELAt, many networks and other strong public-private-HEI cooperations are present in the cross-border region. Although collaboration in project and policy-making increasingly takes a triple helix forms (including universities), formal governance structures are still entirely public sector driven. As the examples of the Transnational University Limburg and other joint research institutions show, there is a high level of institutionalisation in the TTR-ELAt cross-border region.

\section{6 Öresund}

The Öresund region has long enjoyed international visibility and prominence because of the breathtaking engineering effort that was made to create a bridge between the two halves of the region, across the Öresund strait. Partners across the region worked hard to create a sense of possibility for this new region as a means of justifying the financial investment necessary to complete the joint tunnel-bridge arrangement within the framework of the European Union's Trans-European Network policy. The imaginary 
constructed was on a new high-technology region for Europe, bringing together metropolitan Copenhagen with the old industrial city of Malmo and the elite university town of Lund to create a dynamic innovation space, and critically to stimulate new economic opportunities in those parts of Oresund outside metropolitan Copenhagen. Although both sides of the border have very strong innovation economies, there remains a divergence between the service based greater Copenhagen and the rest of the Öresund that is more dependent on knowledge-based manufacturing industries; it is that element which represents the greatest barrier to innovation co-operation.

Co-financed by Danish and Swedish national and regional sources in 1998, the Öresund University was established among fourteen universities and university colleges from both sides of the border (Nauwelaers, et al., 2013d). Although the Öresund University was formally resolved in 2010, smaller cross-border co-operation and collaboration between HEIs in the cross-border region continue in different forms until today (Nauwelaers, et al., 2013d). For example, for doctoral students, joint PhD programmes are offered. Furthermore, joint proof-of-concept programmes for research funding are offerend in the Öresund cross-border area (Nauwelaers, et al., 2013d). With regard to research activities, program-based scientific collaboration takes place in the field of biotechnology (Nauwelaers, et al., 2013d). In addition, HEIs are cooperating in a number of various temporary Interreg projects (Nauwelaers, et al., 2013d). Furthermore since the opening of the Öresund Bridge, the number of co-authorships in the fields of biotechnology has increased (Nauwelaers, et al., 2013d). During 2001 - 2004, third mission activities in the Öresund cross-border area were regulized by the Öresund Contracts, which set out the basic conditions for cooperation between companies, universities and research institues in the cross-border area (Nauwelaers, et al., 2013d). With regard to the role of universities in the formal governance structure of the cross-border region, it is reported that universities do take part in governance structures to some degree, since they are initators for bross-border linkages. One example for this is the Medicon Valley Alliance, which is a cross-border cluster organisation in fields related to the pharmaceutical industry that was initiated by universities located in the Öresund cross-border area in 1997. 


\section{A first characterisation of the transformative effects of universities in CBRISs}

Considering our results from the previous section, it can be seen that in all six crossborder regions HEIs cooperate in some way in the education domain. Mostly this takes the form of joint courses and doctoral schools. The most advanced with this respect seems to be in the Bothnian Arc and the TTR-ELAt regions, where double degrees are rewarded in the Nordic Mining School and the Transnational Limburg University. The Öresund University was a leading example until 2010, but was then resolved into smaller collaborations. With respect to the research function of HEIs we see two different directions. On the one hand there are the regions in which the HEIs are more driven towards international research collaboration then cross-border collaboration. The other examples show stronger development towards a joint research infrastructure with joint research programs and student/staff exchange. The most far-reaching example is the Holst Centre in TTR-ELAt, a joint venture of the Dutch institute for applied research and the Belgian IMEC research centre. Here a joint institute is established, funded from structural funding sources (as opposed to most ad hoc projects).

The third mission activities are less easily observable in these six regions. HEIs participate in diverse cluster initiatives and ad hoc projects bringing business and HEIs together. A good example of such an initiative is the Medicon Valley Alliance in Öresund focused on cooperation in the pharmaceutical industry (Park, 2014). Cross-border third mission activities are strongly influenced by the level of institutionalisation and ways of implementing of third mission activities in the respective countries, which for example in the Bothian Arc led to less cross-border innovation-related activities in general (Nauwelaers, et al., 2013e). As part of the third mission engagement of universities, they can play a role in the governance of cross-border cooperation. However, only in the Öresund region there is some participation in the governance of the cross-border region. Even in the advanced TTR-ELAt region, although there are several private initiatives and there is strong cooperation between research institutes, HEIs play no role in the governance of the cross-border region. This is partly due to the lack of a dedicated body for the border region, and HEIs play an active role in the triple helix bodies of the 
respective regions. In the other four regions the governance structure is entirely dominated by public actors. The Medicon Valley Alliance, Transnational Limburg University and the Holst Centre are the clearest examples of cross-border institutions. In the Nordic regions and the Baltic Sea area institutionalised university networks exist that comprise the universities in the respective case study regions, but have a much larger and thereby more general focus.

Using our conceptual typology, we can see that with regard to universities internal activities most cross-border cooperation in these six border regions is centred around education and to a lesser extent on research activities. Most of the research activities take the form of bottom-up initiatives between individuals in the cross-border HEIs. However, a high number of bottom-up research initiatives does not necessary imply a high level of regional integration, since most bottom-up research initiatives are vulnerable to human factors (e.g. personalised relationships) and/or restricted in time (project-based). Nevertheless, it provides us with some indication for an increased level of cross-border collaboration between HEIs in the cross-border region that might lead to more integration activities in the future. Education activities otherwise seem to require more often a higher level of institutional integration, since joint cross-border education activities (e.g. joint course, joint programmes) need to be formally be approved and regulated by both HEIs on both sides of the border. Consequently, the amount of joint cross-border education activities provides us with some indication for a higher level of regional integration.

Regarding universities external activities, there are only few examples of cross-border third mission activities and HEIs hardly play a role in any of the governance structures of the six cross-border regions. This indicated that the amount of cross-border collaboration in internal activities does not necessary has an impact on the integration in external activities. At least in form of having a seat at the table, it might be that they influence the policies via the execution of background studies or consultancy activities.

As the results of the analysis show, most cross-border collaboration between HEIs appears in border regions that show already a higher level of integration in other domains related to innovation. Consequently, from our analysis above it becomes not clear 
whether cross-border collaboration between HEIs drives or are driven by regional crossborder integration. 
Table 2. Universities' internal and external activities in the six cross-border regions.

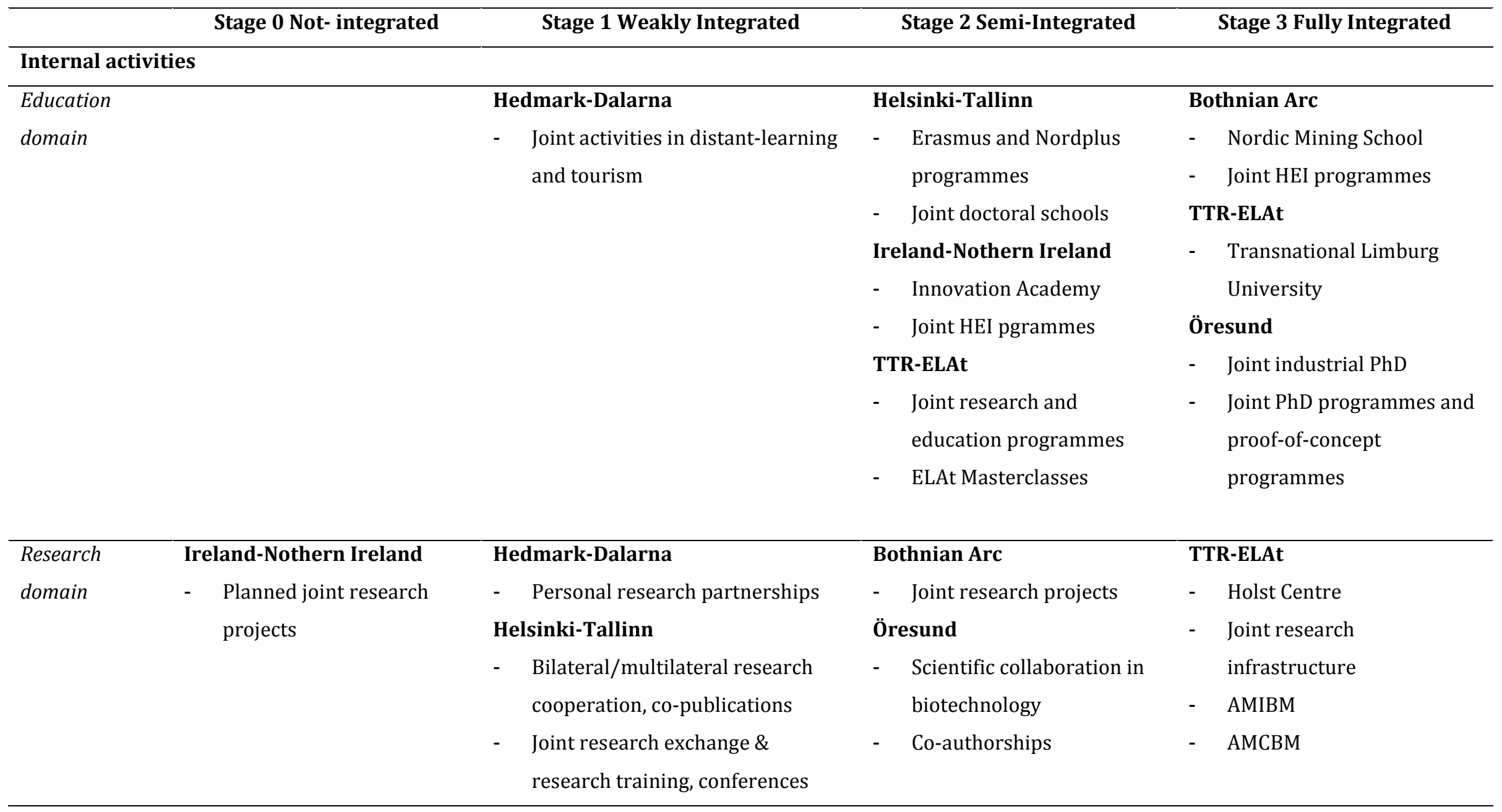




\begin{tabular}{|c|c|c|c|c|}
\hline \multicolumn{5}{|c|}{ External activities } \\
\hline $\begin{array}{l}\text { Third mission } \\
\text { activities }\end{array}$ & $\begin{array}{l}\text { Hedmark-Dalarna } \\
\text { - } \quad \text { Not reported }\end{array}$ & $\begin{array}{l}\text { Helsinki-Tallinn } \\
-\quad \text { Helsinki-Tallinn Science Bridge } \\
\text { Ireland-Nothern Ireland } \\
-\quad \text { FUSION }\end{array}$ & $\begin{array}{l}\text { Bothnian Arc } \\
\text { - } \quad \text { Five joint academic } \\
\text { research and business } \\
\text { initiatives } \\
\text { TTR-ELAt } \\
\text { - } \quad \text { Networks (triple helix) } \\
\quad \text { initiatives }\end{array}$ & $\begin{array}{l}\text { Öresund } \\
-\quad \text { Öresund Contracts }\end{array}$ \\
\hline Governance & $\begin{array}{l}\text { Hedmark-Dalarna } \\
\text { - } \quad \text { Only public actors } \\
\text { Helsinki-Tallinn } \\
\text { - } \quad \text { Only public actors } \\
\text { Ireland-Nothern } \\
\text { Ireland } \\
\text { - } \quad \text { Only public actors }\end{array}$ & $\begin{array}{l}\text { Bothnian Arc } \\
\text { - } \quad \text { HEIs are involved in concrete } \\
\text { projects, but not contribute to the } \\
\text { vision or strategy of the cross- } \\
\text { border region } \\
\text { TTR-ELAt } \\
\text { - } \quad \text { HEIs influence in policy making } \\
\text { and projects increases through } \\
\text { triple helix initiatives }\end{array}$ & $\begin{array}{l}\text { Öresund } \\
\text { - } \quad \text { HEIs are to a certain } \\
\text { degree part of the } \\
\text { governance structure }\end{array}$ & \\
\hline $\begin{array}{l}\text { Institutional } \\
\text { collaboration }\end{array}$ & $\begin{array}{l}\text { Ireland-Nothern } \\
\text { Ireland } \\
\text { - } \quad \text { No institutionalised } \\
\text { cooperation among } \\
\text { HEIs }\end{array}$ & $\begin{array}{l}\text { Hedmark-Dalarna } \\
\text { - } \quad \text { UNISKA university network }\end{array}$ & $\begin{array}{l}\text { Bothnian Arc } \\
-\quad \text { Nordic Mining School } \\
\text { Helsinki-Tallinn } \\
-\quad \text { Joint research councils } \\
-\quad \text { Baltic University } \\
\quad \text { Program }\end{array}$ & $\begin{array}{l}\text { TTR-ELAt } \\
-\quad \text { Transnational Limburg University } \\
\text { - } \quad \text { Holst Centre } \\
\text { Öresund } \\
\text { - } \quad \text { Medicon Valley Alliance }\end{array}$ \\
\hline
\end{tabular}




\section{Conclusions}

The aim of this working paper has been to answer the question of what roles do universities play in $\mathrm{CB}$ regions and how can we understand these roles through a conceptual typology? In order to achieve that goal, we have constructed a conceptual typology of university contributions to CBRISs to understand how universities (can) contribute to cross-border integration. We have explored the constructed typology by looking at six cases of cross-border innovation, and Table 2 presented above offers an overview of university activities in these six cases. Looking more closely at this synthesis, we would seek to make three tentative points as the basis for our wider conclusions. Firstly, there is evidence that universities can play various kinds of cross-border RIS transformation roles in the various domains identified. Secondly, that there appears to be a co-evolution of these activities as CBRISs themselves dominate, with eventually, in some regions, the emergence of critical mass associated with integration. Thirdly, at the early stage of these involvements, they are articulated around limited-life projects, and therefore there seems to be a window of opportunity for these experimental efforts to become institutionalised and the basis for further integration activity.

First, cross-border university activities can be found across all domains of university activity and in all three stages of integration. Most activities are found within the education and research domain but universities are also working with firms across the border and collaborate in triple helix constellations. We did hardly see any universities participate in the governance structure of cross-border regions, this remains a collaboration between public partners on both sides of the border. The majority of the activities is taking place in the education domain where universities are contributing to the construction of a cross-border labour market, which can be important source of knowledge exchange and an important contribution to the development of a CBRIS. With regard to the different stages of integration we saw different kinds of activities in terms of effort needed and people involved which we understand as activities in different stages of the model. That indicates that universities contribute throughout the process of crossborder integration in different ways. Whether the university activity contributes to crossborder integration is dependent on how joint programs, joint degrees and joint 
infrastructure are designed. The mere presence of an activity does not necessarily lead to more integration but is an indication that integration is taking place. This corresponds to the integrative dimension of the model, that universities are involved with the build-up of CBRISs.

Second, cross-border university activities seem to co-evolve with the integration of the cross-border region on other themes. Two regions, TTR-ELAt and Bothnian Arc, dominate the activities in the semi-integrated and fully-integrated stage of integration. These are also the two regions that according to the OECD (2013) are the most integrated regions on all domains related to innovation and are in general considered to be examples of successful cross-border integration. At the very least we can thus say that university activities seem to co-evolve with the integration, whilst it would require an in-depth analysis to determine what has been the contribution of the university activities to this integration process. It might be tempting to see here with the case of TTR-ELAt that there is a Matthew Principle at play - that is to say because the region is technologically strong then universities find it easy to integrate and co-operate. Although that is of itself true, it is not true of the Bothnian Arc, where there has been integration of HE in the way that has not been achieved in Hedmark-Dalarna. This suggests that the universities in this case are exerting agency to create something new that corresponds to the transformative dimension of our model.

Third, whilst the discourse around cross-border integration suggests a linear path towards further integration we see that the cross-border activities of universities are for an important part project-based and can also be stopped. We saw that in the Öresund area the cross-border university was split-up into several smaller initiatives and recently the Holst centre in TTR-ELAt, although championed by many as a leading example of crossborder collaboration on innovation, has experienced a period of uncertainty over its funding. Whilst cross-border university activities are mostly welcomed by other regional and national partners, the amount of structural funding both from the university as from external sources is limited making the initiatives vulnerable for shifting priorities. This provides more insights into our overall model - because of the need for universities to be clear about the way that these extremely risky, uncertain activities can create enrichment 
benefits for core teaching and research activities, there is a set of experiments which if successful may be capitalised upon. Promoting university transformative engagement in CBRISs need therefore to pay particular attention in ensuring that the benefits for the universities remain clear and concrete in the overall calculus to allow this transformation to take root within the university institutional structure.

Our overall aim in this working paper has not just been to study cross-border regions, although they are of course an important feature for Europe, with 30\% of Europe's population living in border regions (Apokov et al, 2008). The wider message relates to the capacities of universities to contribute to transformative change processes, and in particular to create new kinds of opportunities in those places where the systems, networks and structures for these things does not exist. Universities are capable of building networks and systems across national borders that can create systematic effects, to improve the overall innovation environments in particular regards. They do so through a process of experimentation where they attempt to build regional networks that can create benefits for their internal knowledge activities, and if they succeed, there is then a limited window of opportunity to institutionalise them into more enduring activities and institutions.

And in our mind this provides a useful way of understanding the third, transformative, dimension of universities' regional contributions that has clear salience to this volume's debates regarding universities' contributions to regional economic development. The bulk of university contributions will come through these generative and developmental contributions, operating within and improving existing systems. But there is an opportunity for them to play this transformative role, creating new chances for regional innovation in these places. And yet, we are struck at how limited this role has been played across Europe, and we therefore assume that it is hard to find ways to couple the undoubted external benefits to the internal enrichment benefits for core university teaching and research activities. And this is where we believe the future research agenda lies, in understanding more systematically the ways in which universities more generally in sparse innovation environments are do or do not succeed in their transformative interventions. 


\section{References}

Akopov, S. Haselsberger, B. \& Karadimitriou, N. (2008) Territorial cohesion versus variation and diversity: the hallmark of supranational territories, Regions, 270, pp. 11-12, doi: $10.1080 / 13673882.2008 .8628865$

Arbo, P., \& Benneworth, P. (2007). Understanding the regional contribution of higher education institutions: A literature review. OECD, Directorate for Education, Working Paper N. 9, (9), 1-78. http://doi.org/10.1787/161208155312

Bathelt, H., A. Malmberg and P. Maskell (2004), “Clusters and Knowledge: Local Buzz, Global Pipelines and the Process of Knowledge Creation", Progress in Human Geography, 28, pp. 31-56.

Benneworth, P. (2014) "Decoding university ideals by reading campuses" in P. Temple (ed.) The physical university, London: Routledge.

Benneworth, P. \& Osborne, M. (2014) "Knowledge, engagement, and higher education in Europe" in (eds) R. Tandon \& B. Hall, Higher Education in the World 5: Knowledge engagement and higher education: contributing to social change, London: Palgrave Macmillan.

Benneworth, P., Coenen, L., Moodysson, J., \& Asheim, B. (2009). Exploring the Multiple Roles of Lund University in Strengthening Scania's Regional Innovation System: Towards Institutional Learning? European Planning Studies, 17(11), 1645-1664. JOUR.

Cairncross F. (1997) The Death of Distance: How the Communications Revolution Will Change Our Lives. Texere, London.

Caniëls, M. C. J., \& van den Bosch, H. (2011). The role of Higher Education Institutions in building regional innovation systems. Papers in Regional Science, 90(2), 271-286. http://doi.org/10.1111/j.1435-5957.2010.00344.x

Centre for Educational research and innovation (1982) The university and the community: the problems of changing relationships, Paris: OECD

Charles, D., Kitagawa, F., \& Uyarra, E. (2014). Universities in crisis?-new challenges and strategies in two English city-regions. Cambridge Journal of Regions, Economy and Society, 7(2), 327-348. http://doi.org/10.1093/cjres/rst029

Cooke, P. (1992). Regional innovation systems: competitive regulation in the new Europe. Geoforum, 23(3), 365-382.

Cooke, P. (2005) Regionally asymmetric knowledge capabilities and open innovation: exploring 'Globalisation 2' - a new model of industry organisation, Research Policy, 34, pp. 11281149

Cooke, P. and Piccaluga, A. (Eds) (2004) Regional economies as knowledge laboratories. (Cheltenham: Edward Elgar)

Economics Intelligence Unit (2016) "Spatial alchemy: why proximity matters for innovation" Economic Intelligence Unit Briefing Paper, London: EIU, Available online at 
http://destinationinnovation.economist.com/wpcontent/uploads/sites/3/2016/07/Destination-InnovationSpatial_alchemy_why_proximity_matters_for_innovation.pdf

Goddard, J. B., \& Chatterton, P. (2003). The response of universities to regional needs. In R. Rutten, F. Boekema, \& E. Kuijpers (Eds.), Economic Geography of Higher Education: Knowledge, Infrastructure and Learning Regions, Routledge, London (pp. 19-41). JOUR, Routledge.

Gunasekara, C. (2006a) Reframing the role of universities in the development of regional innovation systems, Journal of technology transfer 31 (1) pp. 101-111.

Gunasekara, C. (2006b) Universities and associative regional governance: Australian evidence in non-core metropolitan regions. Regional Studies 40(7):pp. 727-741.

Gunasekara, C. (2006c), 'Leading the horses to water: the dilemmas of academics and university managers in regional engagement', Journal of Sociology , 42, 145-163.

Gunasekara, C. (2006d). The generative and developmental roles of universities in regional innovation systems. Science and Public Policy, 33(2), 137-150. doi: $10.3152 / 147154306781779118$

Haselsberger, B.; Benneworth, P. (2011) Cross-border Communities or Cross-border Proximity? Perspectives from the Austrian-Slovakian Border Region. In: Adams, N. et al. (Eds.) Territorial Development, Cohesion and Spatial Planning. Knowledge and policy development in an enlarged EU. Routledge, pp.229-254

Kempton, L. (2015). Delivering smart specialization in peripheral regions: the role of Universities. Regional Studies, Regional Science, 2(1), 488-495. JOUR.

Lawton Smith, H., Glasson, J., and Chadwick, A. (2005) The geography of talent: entrepreneurship and local economic development in Oxfordshire. Entrepreneurship and Regional Development, 17: 449-476

Lawton Smith, H., Glasson, J., Simmie, J., Chadwick, A. \& Clark, G. (2003) Enterprising Oxford: the growth of the Oxfordshire high technology economy, Oxford: Oxfordshire Economic Observatory.

Lundquist, K.-J., \& Trippl, M. (2013). Distance, Proximity and Types of Cross-border Innovation Systems: A Conceptual Analysis. Regional Studies, 47(3), 450-460.

Mansfield, E. (1991). Academic research and industrial innovation. Research Policy, 20(1), 1-12. JOUR.

McCann, P., \& Ortega-Argilés, R. (2013). Modern regional innovation policy. Cambridge Journal of Regions, Economy and Society, 6, 187-216. http://doi.org/10.1093/cjres/rst007

Nauwelaers, C., Maguire, K., \& Marsan, G. A. (2013a). The Case of Hedmark-Dalarna (NorwaySweden) Regions and Innovation: Collaborating Across Borders (OECD Regional Development Working Papers No. 18). 
Nauwelaers, C., Maguire, K., \& Marsan, G. A. (2013b). The Case of Helsinki-Tallinn ( FinlandEstonia ) - Regions and Innovation: Collaborating Across Borders (OECD Regional Development Wokring Papers No. 19).

Nauwelaers, C., Maguire, K., \& Marsan, G. A. (2013c). The Case of Ireland-Northern Ireland ( United Kingdom ) - Regions and Innovation: Collaborating Across Borders (OECD Regional Development Working Papers No. 20).

Nauwelaers, C., Maguire, K., \& Marsan, G. A. (2013d). The case of Oresund (Denmark-Sweden) Regions and Innovation : Collaborating Across Borders (OECD Regional Development Working Papers No. 21).

Nauwelaers, C., Maguire, K., \& Marsan, G. A. (2013e). The Case of the Bothnian Arc ( FinlandSweden ) - Regions and Innovation: Collaborating Across Borders (OECD Regional Development Working Papers No. 17).

Nauwelaers, C., Maguire, K., \& Marsan, G. A. (2013f). The Case of the Top Technology Region / Eindhoven-Leuven-Aachen Triangle ( TTR-ELAt ) - Regions and Innovation: Collaborating Across Borders (OECD Regional Development Working Papers No. 22).

Nelles, J., \& Durand, F. (2014). Political rescaling and metropolitan governance in cross-border regions: comparing the cross-border metropolitan areas of Lille and Luxembourg. European Urban and Regional Studies, 21(4), 104-122. JOUR. http://doi.org/10.1177/0969776411431103

OECD. (2013). Regions and Innovation: Collaborating Across Borders (OECD Revie). OECD Publishing. http://doi.org/10.1787/9789264205307-en

Park, S. C. (2014). Innovation policy and strategic value for building a cross-border cluster in Denmark and Sweden. AI and Society, 29(3), 363-375. http://doi.org/10.1007/s00146013-0460-4

Power, D., \& Malmberg, A. (2008). The contribution of universities to innovation and economic development: in what sense a regional problem? Cambridge Journal of Regions, Economy and Society, 1(2), 233-245. JOUR.

Ruan, X., Saad, M. ed, Kumar, V. and Kumari, A. (2015) Challenges to the transformational role of university in regional innovation system. In: BAM 2015 Annual Conference, Portsmouth University, UK, 8-10 September 2015.

Sánchez-Barrioluengo, M. (2014). Articulating the "three-missions" in Spanish universities. Research Policy, 43(10), 1760-1773. http://doi.org/10.1016/j.respol.2014.06.001

Saxenian, A. (1985) 'The genesis of Silicon Valley' in P. Hall, \& A. Markusen (eds) Silicon landscapes, Boston, MA: Allen \& Unwin.

Saxenian, A. (1992) 'Contrasting patterns of business organisation in Silicon Valley' Environment \& Planning D: Society \& Space 10 (3) pp. 377-391.

Segal Quince Wicksteed (2003) "Knowledge transfer in Scotland: a scoping study" report for SHEFC: Edinburgh, Scotland: SHEFC. 
Segal, N. (1985) The Cambridge phenomenon — the growth of high technology industry in a university town, Cambridge, Segal, Quince and Partners.

Tian Miao, J. Benneworth, P. \& Phelps, N. (eds) (2015) Making 21st century knowledge complexes: technopoles of the world 20 years after, London: Routledge.

Trippl, M. (2010). Developing Cross-Border Regional Innovation Systems: Key Factors and Challenges. Tijdschrift Voor Economische En Sociale Geografie, 101(2), 150-160. JOUR.

Trippl, M., Sinozic, T., \& Lawton Smith, H. (2015). The Role of Universities in Regional Development: Conceptual Models and Policy Institutions in the UK, Sweden and Austria. European Planning Studies, (June), 1-19. http://doi.org/10.1080/09654313.2015.1052782

Uyarra, E. (2009). What is evolutionary about "regional systems of innovation"? Implications for regional policy. Journal of Evolutionary Economics, 20(1), 115-137. JOUR.

Uyarra, E. (2010). Conceptualizing the Regional Roles of Universities, Implications and Contradictions. European Planning Studies, 18(8), 1227-1246.

http://doi.org/10.1080/09654311003791275

Van den Broek, J., Benneworth, P., \& Rutten, R. (2015). Border blocking effects in collaborative firm innovation. Conference Paper.

Van den Broek, J., Benneworth, P., \& Rutten, R. (2016). Border blocking effects in collaborative firm innovation (No. 02/2016). CHEPS WORKING PAPER SERIES. Enschede.

Van den Broek, J., \& Smulders, H. (2014). Institutional gaps in cross-border regional innovation systems : The horticultural industry in Venlo-Niederrhein. In R. Rutten, P. Benneworth, D. Irawati, \& F. Boekema (Eds.), The social dynamics of innovation networks (pp. 157-175). London: Routledge.

Van Houtum, H. (1998). The development of cross-border economic relations. B0OK, Tilburg: Tilburg University Press. 
The Center for Higher Education Policy Studies (CHEPS) is a research institute (WHW, Article 9.20) located in the Faculty of Behavioural and Management Sciences within the University of Twente, a public university established by the Dutch government in 1961. CHEPS is a specialized higher education policy centre that combines basic and applied research with education, training and consultancy activities.

Center for

Higher Education

Policy Studies 